Bangladesh J. Sci. Ind. Res. 42(3), 311-316, 2007

\title{
Studies on the Fatty Acid Composition of Edible Oil
}

\author{
K. Chowdhury, L. A. Banu, S. Khan and A. Latif \\ IFST, BCSIR, Dhaka-1205, Bangladesh
}

\begin{abstract}
Fatty acid analysis of the five types of locally consumed edible oils $(\mathrm{n}=22)$ was carried out using a Gas Chromatograph (G.C) equipped with a Flame Ionization Detector (FID) and stainless steel packed column. The results showed that sunflower oil contained the highest percentage of long chain mono and polyunsaturated fatty acids (91.49 $\pm 1.91 \%$ ) compared to soybean oil (81.14 $\pm 1.49 \%$ ), mustard oil (86.80 $\pm 3.07 \%$ ), palm oil (53.30 $\pm 0.36 \%)$ and coconut oil (7.12 $\pm 0.51 \%)$. Two varieties of mustard oil, low erucic ( $5 \%, \mathrm{n}=3)$ and high erucic acid ( $>14 \%, \mathrm{n}=2)$ and two varieties of sunflower oil, high linoleic-low oleic (61-66 \% \& 22-27 \%, n=2) and low linoleic- high oleic (29-38 \% and 53-63 \%, n=3) were found. Sunflower oil with the highest percentage of mono and polyunsaturated fatty acids especially the high linoleic-low oleic variety appeared to be superior and most suitable edible oil for mass consumption.
\end{abstract}

Key words: Fatty acid, Gas chomatograph, Sunflower oil, Soybean oil, Mustard oil, Palm oil, Coconut oil.

\section{Introduction}

Edible oil is an essential nutrient and an important source of energy providing 9 $\mathrm{kcal} / \mathrm{g}$. For oil to be utilized as a source of energy it must be well digested and absorbed into the body (Tannenbaum, 1979). Oils in the diet are available to the body as fatty acids, which are excellent sources of dietary calorie intake. Fatty acids (FAs) are classified as saturated (SFA), monounsaturated (MUFA) and poly-unsaturated (PUFA) fatty acids. The total energy intake from oils for a normal healthy adult is approximately 30 energy percent and that in the western diets is about 40 energy percent. High fat diets enhance the incidence of coronary heart disease (Romon et al. 1995 and Simon et al. 1995). Risk factors for coronary heart disease (CHD) such as elevated levels of serum total cholesterol, low density lipoprotein cholesterol (LDL-C), serum triglycerides (TG) and reduced levels of high density lipoprotein cholesterol (HDL-C) are modulated by the fat content in the diet. A high intake of saturated fatty acids and cholesterol in the diet 
may lead to hypercholesterolaemia, largely through an increase in LDL-C. On the contrary, polyunsaturated fatty acids have a hypocholesterolaemic effect in human (Sundram, K. 2003). Deficiency of essential fatty acids (EFA) such as linoleic (18:2), linolenic (18:3) and arachidonic acid (20:4), growth is retarded and dermal symptoms appear. Patients with chronic intestinal disorders causing malabsorption, nutritional losses through diarrhoea or catabolic illness would be expected to have EFA deficiency (Kaul et al. 1986, Okeef, 1996 and Siguel et. al.1996).

The aim of this study was to find out a suitable variety of locally available edible oil rich in essential fatty acids for general mass to combat malnutrition.

\section{Materials and Methods}

Edible oil samples of five different varieties: sunflower oil (5 samples), soybean oil (3 samples), palm oil (3 samples), mustard oil (5 samples) and coconut oil (6 samples) were collected from local market during the period between July 2002 to June 2003.

\section{Preparation of fatty acid methyl ester (FAME)}

Relative concentration of fatty acid (FA) from oil samples were measured as their corresponding methyl esters according to the method described in IUPAC (1979) with a minor modification. 5-7 drops ( 50 $\mu$ l each) of oil was taken in $15 \mathrm{ml}$ test tube and $3 \mathrm{ml}$ of $0.5 \mathrm{M}$ sodium methoxide (prepared by mixing metallic sodium in methanol) was added and digested by stirring in a boiling water bath for about 15 minutes. It was allowed to cool to room temperature and $1 \mathrm{ml}$ of petroleum ether (b.p $40-60^{\circ} \mathrm{C}$ ) was added followed by $10 \mathrm{ml}$ deionized water, mixed gently and allowed to settle for some time. The distinct upper layer of methyl ester in petroleum ether was separated carefully in a capped vial and used for analysis. $200 \mathrm{mg}$ of different fatty acid standards in their respective methyl ester form were dissolved separately in $10 \mathrm{ml}$ petroleum ether (b.p 40-60 C) in a series of screw capped test tubes. Aliquots of $1 \mu \mathrm{L}$ FAME was injected and peaks were recorded for their respective retention time and areas by the data processor unit of the GC.

\section{Chromatography}

Analysis of FAME was carried out on Gas Chromatograph (GC) Model-14B, Shimadzu, Japan loaded with software Class GC-10 (version-2.00). The GC was equipped with Flame Ionization Detector (FID) and stainless steel column, dimension $10 \mathrm{X} 1 / 8$, packed with $5 \%$ DEGS-PS. The column was conditioned at $180^{\circ} \mathrm{C}$ about 2 hours for attaining thermal stability before use. The operating condition was programmed at oven temperature $150^{\circ} \mathrm{C}$ (hold time $5 \mathrm{~min}$ ) with increasing rate $8^{\circ} \mathrm{C} / \mathrm{min}$ to $190^{\circ} \mathrm{C}$ (hold time $0 \mathrm{~min}$ ), $2^{\mathrm{O}} \mathrm{C} / \mathrm{min}$ to $200^{\circ} \mathrm{C}$ (hold time $10 \mathrm{~min})$, injection temperature $250^{\circ} \mathrm{C}$ and 
detector temperature $250^{\circ}$ C. Nitrogen was used as a carrier gas with flow rate of 20 $\mathrm{ml} / \mathrm{min}$.

\section{Results and Discussion}

A total of 22 edible oil samples collected from the local markets were analyzed using gas chromatograph for their fatty acid (FA) compositions of them, five samples were of sunflower oil, three of soybean oil, five of mustard oil, three of palm oil and six of coconut oil. Their respective fatty acid (FA) percent composition are shown in Table-I and the mean of total saturated fatty acid (SFA), monounsaturated fatty acid (MUFA) and polyunsaturated fatty acid (PUFA) percent are shown in Table II. Table III shows the varieties of mustard oil and sunflower oil.

Table I. Fatty acid composition of different types of edible oil

\begin{tabular}{l|c|c|c|c|c}
\hline Fatty acids \% & $\begin{array}{c}\text { Sunflower oil } \\
(\mathrm{n}=5) \\
\text { Mean } \pm \text { SD }\end{array}$ & $\begin{array}{c}\text { Soybean oil } \\
(\mathrm{n}=3) \\
\text { Mean } \pm \text { SD }\end{array}$ & $\begin{array}{c}\text { Mustard oil } \\
(\mathrm{n}=5) \\
\text { Mean } \pm \text { SD }\end{array}$ & $\begin{array}{c}\text { Palm oil } \\
(\mathrm{n}=3) \\
\text { Mean } \pm \text { SD }\end{array}$ & $\begin{array}{c}\text { Coconut oil } \\
(\mathrm{n}=6) \\
\text { Mean } \pm \text { SD }\end{array}$ \\
\hline Caprylic $\left(\mathrm{C}_{8: 0}\right)$ & -- & -- & -- & -- & $6.21 \pm 0.34$ \\
Capric $\left(\mathrm{C}_{10: 0}\right)$ & -- & -- & -- & -- & $6.15 \pm 0.21$ \\
Lauric $\left(\mathrm{C}_{12: 0}\right)$ & -- & -- & -- & -- & $51.02 \pm 0.71$ \\
Myristic $\left(\mathrm{C}_{14: 0}\right)$ & -- & -- & -- & $1.23 \pm 0.28$ & $18.94 \pm 0.63$ \\
Palmitic $\left(\mathrm{C}_{16: 0}\right)$ & $6.52 \pm 1.75$ & $14.04 \pm 0.62$ & $4.51 \pm 3.83$ & $41.78 \pm 1.27$ & $8.62 \pm 0.50$ \\
Stearic $\left(\mathrm{C}_{18: 0}\right)$ & $1.98 \pm 1.44$ & $4.07 \pm 0.29$ & $2.78 \pm 0.59$ & $3.39 \pm 0.65$ & $1.94 \pm 0.17$ \\
Oleic $\left(\mathrm{C}_{18: 1}\right)$ & $45.39 \pm 18.77$ & $23.27 \pm 2.43$ & $38.21 \pm 21.88$ & $41.90 \pm 1.20$ & $5.84 \pm 0.50$ \\
Linoleic $\left(\mathrm{C}_{18: 2}\right)$ & $46.02 \pm 16.75$ & $52.18 \pm 2.64$ & $25.31 \pm 5.74$ & $11.03 \pm .02$ & $1.28 \pm 0.18$ \\
Linolenic $\left(\mathrm{C}_{18: 3}\right)$ & $0.12 \pm 0.09$ & $5.63 \pm 3.48$ & $11.30 \pm 6.09$ & -- & -- \\
Arachidic $\left(\mathrm{C}_{20: 0}\right)$ & -- & -- & $10.86 \pm 3.29$ & -- & -- \\
Erucic $\left(\mathrm{C}_{22: 1}\right)$ & -- & -- & $11.35 \pm 13.83$ & -- & -- \\
\hline
\end{tabular}

Table II. Percentage of saturated (SFA), monounsaturated (MUFA), polyunsaturated (PUFA) and total unsaturated (MUFA+ PUFA) fatty acid of each types of oil

\begin{tabular}{c|c|c|c|c|c}
\hline Fatty acids \% & $\begin{array}{c}\text { Sunflower Oil } \\
(\mathrm{n}=5) \\
\text { Mean } \pm \text { SD }\end{array}$ & $\begin{array}{c}\text { Soybean Oil } \\
(\mathrm{n}=3) \\
\text { Mean } \pm \text { SD }\end{array}$ & $\begin{array}{c}\text { Mustard Oil } \\
(\mathrm{n}=5) \\
\text { Mean } \pm \text { SD }\end{array}$ & $\begin{array}{c}\text { Palm Oil } \\
(\mathrm{n}=3) \\
\text { Mean } \pm \text { SD }\end{array}$ & $\begin{array}{c}\text { Coconut Oil } \\
(\mathrm{n}=6) \\
\text { Mean } \pm \text { SD }\end{array}$ \\
\hline SFA & $8.51 \pm 1.91$ & $18.26 \pm 0.67$ & $15.94 \pm 2.58$ & $46.34 \pm 0.40$ & $92.92 \pm 0.56$ \\
MUFA & $45.5 \pm 16.89$ & $23.28 \pm 1.99$ & $49.57 \pm 8.56$ & $41.46 \pm 0.56$ & $5.84 \pm 0.46$ \\
PUFA & $46.10 \pm 14.92$ & $57.86 \pm 1.20$ & $36.62 \pm 6.42$ & $11.84 \pm 0.92$ & $1.28 \pm 0.17$ \\
MUFA + PUFA & $91.49 \pm 1.91$ & $81.14 \pm 1.49$ & $86.18 \pm 3.07$ & $53.30 \pm 0.36$ & $7.12 \pm 0.51$ \\
\hline
\end{tabular}


Table III. Varieties of sunflower and mustard oil

\begin{tabular}{c|c|c|c|c}
\hline & \multicolumn{2}{|c|}{ Sunflower oil variety(n=5) } & \multicolumn{2}{c}{ Mustard oil variety(n=5) } \\
\hline & \multicolumn{2}{|c|}{ i. High linoleic- low oleic } & \multicolumn{2}{c}{ i. High erucic acid } \\
\hline Sample No. & Linoleic acid (\%) & Oleic acid (\%) & Sample No. & Erucic acid (\%) \\
\hline S-1 & 61.24 & 27.76 & S- 1 & 14.73 \\
S-2 & 66.55 & 22.78 & S-5 & 34.12 \\
\hline \multicolumn{2}{|c|}{ ii. Low linoleic-high oleic } & \multicolumn{2}{c}{ ii. Low erucic acid } \\
\hline S-3 & Linoleic acid (\%) & Oleic acid (\%) & Srucic acid (\%) \\
S-4 & 29.45 & 63.55 & S- 2 & 4.76 \\
S-5 & 34.08 & 59.04 & S- 3 & 2.25 \\
\hline
\end{tabular}

It has been found in this study that sunflower, soybean and palm oils contained four to five FAs (Table I) each, whereas mustard oil and coconut oil contained seven and eight FAs respectively. Two to six different types of saturated FAs of chain length $C_{8}$ to $C_{20}$ and two to four different types of unsaturated FAs of chain length $C_{18}$ to $C_{22}$ were found in all samples. Palmitic acid $\left(\mathrm{C}_{16: 0}\right)$ and stearic acid $\left(\mathrm{C}_{18: 0}\right)$ were common in all the saturates. Oleic acid $\left(\mathrm{C}_{18: 1}\right)$ and linoleic acid $\left(\mathrm{C}_{18: 2}\right)$ were common in the unsaturated FAs of all oils. Coconut oil, a nontraditional edible oil contained the highest number (six) and highest percentage $(93 \%)$ of SFA $(92.92+0.56)$. Palm oil contained nearly $47 \%$ SFA (46.34 \pm $0.40)$ where palmitic $\left(\mathrm{C}_{16: 0}\right)$ acid was predominant (41.78 \pm 1.27). The major unsaturated FA of this oil was oleic acid (41.90 \pm 1.20). Sunflower oil contained the lowest percentage of SFA (8.51 \pm 1.91$)$ followed by mustard oil (15.94 \pm 2.56$)$ and soybean oil (18.26 \pm 0.67). Mustard oil contained two MUFAs, oleic $\left(\mathrm{C}_{18: 1}\right)$ and erucic $\left(\mathrm{C}_{22: 1}\right)$ acid.
This oil contained the highest percentage of monounsaturated FAs (49.57 \pm 8.56) followed by sunflower (45.5 \pm 16.89), palm (41.46 \pm 0.56$)$ and soybean oil (23.28 \pm 1.99), where oleic acid was predominant. Soybean oil was rich in PUFAs $(57.86 \pm 2.0)$ followed by sunflower ( $46.10 \pm 14.92)$, mustard (36.62 \pm 6.42) and palm oil (11.84 $\pm 0.92)$.

Sunflower and soybean oil contained both the EFAs, linoleic $\left(\mathrm{C}_{18: 2}\right)$ and linolenic $\left(\mathrm{C}_{18: 3}\right)$ acid. The total percentage of essential fatty acids (linoleic and linolenic) in soybean oil is $57.81 \pm 6.12$ and that in sunflower oil is $46.14 \pm 16.84$ (Table. I). Our findings appeared identical with those of earlier published findings (Mowlah et al. 1990) in the context of major fatty acids of the respective oils with the exception of Mustard and Sunflower oil. In Mustard oil, we found two varieties in respect of erucic acid composition (=5 \%, $\mathrm{n}=3$ and $14-34 \%, \mathrm{n}=2)$. In 
Sunflower oil also two types were found in consideration to percent composition of oleic (53-63 \%, n=3 and 22-27 \%, n=2) and linoleic acids (61-66 \%, $\mathrm{n}=2$ and 29-38 \%, $\mathrm{n}=3$ ) (Table III). This variation might be due to difference in the variety of sunflower and mustard seed.

\section{Conclusion}

In consideration of total percentage of unsaturated fatty acids (MUFA+PUFA), Sunflower oil appears superior. On the other hand in respect to total percentage of essential fatty acids (linoleic and linolenic) soybean oil is superior. But on overall consideration, sunflower oil with the highest percentage of mono and polyunsaturated fatty acids especially the high linoleic-low oleic variety appeared to be suitable for mass consumption to combat malnutrition. Proper attention should be given to identify this particular variety of sunflower seed and to promote enhanced production to make it available for general consumption.

\section{Acknowledgement}

This paper is an outcome of $\mathrm{R}$ and $\mathrm{D}$ project work of IFST, BCSIR, Dhaka. The work has been supported by an ADP project funded by the Ministry of Science and Information and Communication Technology, Government of Bangladesh. We are grateful to the BCSIR authorities for providing the scope to conduct the study and to Mr. Zia Ul Abedin,
Application Chemist of AQ Chowdhury Co. Pvt. Ltd. for his technical assistance.

\section{References}

International Union of Pure and Applied Chemistry (IUPAC). (1979) Standard Methods for the Analysis of Oils, Fats \& Derivatives. 6th Ed., Pergamon Press, pp 98-99.

Kaul, A. K. and. Das, M. L (1986) Oilseeds in Bangladesh. Bangladesh: BRAC Printer, Dhaka, pp 273 -28.

Mowlah, G. Sheik, N.M. and Kamal, A.S.M. (1990) A Handbook on edible Oils and Fats (with special reference to Bangladesh). 1st Ed. (The City Press), pp126, 137, 146, 158 and 159.

Okeef, S.J. (1996) Nutrition and gastrointestinal disease. Scand J Gastroenterol Suppl 220 : 52-9.

Romon, M. Nuttens , M.C .and Thaeret, N (1995) Comparison between fat intake assessed by a 3-day food record and phospholipids fatty acid composition of red blood cells : results from monitoring of cardiovascular disease Lille study. Metabolism 44(9): 1139-45.

Siguel Lerman, E.N. R.H. (1996) Prevalence of essential fatty acid deficiency in patients with chronic gastrointestinal disorders. Metabolism 45(1): 12-23. 
Simon, J.A. Fong,J. Bernert Jr, J.T and Browner, W.S.. (1995) Serum fatty acids and the risk of stroke 26(5) 778-82

Sundram, K. (2003) Review Nutritional Properties of palm oil and its products. In: Received : March 19, 2007;

Oil Palm Plantation Management Course. Accepted : July 22, 2007
Tannenbaum, S.R. (1979) Nutritional and safety aspects of food Processing, Marcel Dekker, New York, pp 98. 